УДК 379.85:007

\title{
СИНЕРГЕТИЧНИЙ ПОТЕНЦІАЛ РОЗВИТКУ ТУРИСТИЧНО-РЕКРЕАЦІЙНОї СОЦІО-ЕКОЛОГО-ЕКОНОМІЧНОЇ СИСТЕМИ
}

\section{SYNERGETIC POTENTIAL OF THE DEVELOPMENT OF THE TOURIST AND RECREATIONAL SOCIO-ECOLOGICAL AND ECONOMIC SYSTEM}

\author{
Хитра Олена Володимирівна \\ кандидат економічних наук, доцент, \\ Хмельницький університет управління та права імені Леоніда Юзькова \\ ORCID: https://orcid.org/0000-0003-3558-749X \\ Khytra Olena \\ Leonid Yuzkov Khmelnytskyi University of Management and Law
}

\begin{abstract}
У статті обґрунтовуються ознаки синергетичності туристично-рекреаційної системи, що пов'язана когерентними і коеволюційними взаємозв'язками з іншими галузями економіки, елементами суспільного життя, природним середовищем. Залежність цієї системи, з одного боку, від потреб людини, а з іншого - від рівня науково-технічного прогресу, тенденцій розвитку світового ринку, державного регулювання тощо, обумовлює численні фрлуктуації і велику кількість біфрукаційних гілок еволюції. Проходження через каскад точок біфруркації супроводжується якісними перетвореннями, які змінюють цикли рекреаційної діяльності, рекреаційну місткість та освоєність різних територій. Еволюція туристично-рекреаційних районів відбувається за принципами самоорганізації та синергетичної циклічності і супроводжується наростанням ентропії, для подолання якої пропонується застосовувати інструменти рекреаційного природокористування, збереження культурної самобутності народів і підвищення якості туристичного продукту.
\end{abstract}

Ключові слова: атрактор, біфуркація, емерджентність, ентропія, когерентність, рекреація, самоорганізація, синергія, туризм, флуктуація.

В статье обосновываются признаки синергетичности туристическо-рекреационной системы, связанной когерентными и коэволюционными взаимосвязями с другими отраслями экономики, элементами общественной жизни, природной средой. Зависимость этой системы, с одной стороны, от потребностей человека, а с другой - от уровня научно-технического прогресса, тенденций развития мирового рынка, государственного регулирования и т. п., обусловливает многочисленные флуктуации и большое количество бифуркационных ветвей эволюции. Прохождение через каскад точек бифуркации сопровождается качественными преобразованиями, которые меняют циклы рекреационной деятельности, рекреационную емкость и освоенность различных территорий. Эволюция туристическо-рекреационных районов происходит по принципам самоорганизации и синергетической цикличности, сопровождается нарастанием энтропии, для преодоления которой предлагается применять инструменты рекреационного природопользования, сохранения культурной самобытности народов и повышения качества туристического продукта.

Ключевые слова: аттрактор, бифуркация, эмерджентность, энтропия, когерентность, рекреация, самоорганизация, синергия, туризм, фрлуктуация.

The signs of synergy of the tourist and recreational sphere as a complex socio ecological and economic system, which is connected by coherent and co-evolutionary relationships with other sectors of the economy, elements of social life, the natural environment have been substantiated in the article. The dependence of this system, on the one hand, on human needs, and on the other one on the level of scientific and technological progress, world market trends, government regulation, etc., causes numerous fluctuations and a large number of bifurcation branches of evolution. The passage of the system through a cascade of bifurcation points is accompanied by qualitative transformations that change the cycles of recreational activities, recreational capacity and development of different areas. Attractors of the tourist and recreational system are natural, historical, cultural and socio economic resources, which a kind of magnet attracts it to the desired goal of development, which is formed on a self-organizing basis. These 
attractors are the material basis for the formation and specialization of tourist and recreational areas, the evolution of which is based on the principles of synergetic cyclicity and is accompanied by a periodic increase in entropy, which manifests itself in increasing environmental impact, recreational digression and alienation of foreign cultural values and the gradual loss of ethnic identity. An analogue of negative entropy is the achievement of information ordering of the tourist and recreational system, which may change the degree of its diversity, complexity and dynamism. Measures to comply with the "entropy corridor" should be considered measures for recreational nature, functional zoning of recreational areas, determining the allowable recreational load, streamlining the spatial and territorial location of tourist facilities and more. The author of the article concludes that the use of synergetic management methodology is aimed at search for innovative methods to meet tourist and recreational needs, increase the adaptability of the tourist product to changes in market conditions, as well as increase the socio ecological and economic efficiency of tourism and recreation.

Keywords: attractor, bifurcation, emergence, entropy, coherency, recreation, self-organization, synergy, tourism, fluctuation.

Постановка проблеми. Сучасний туризм $€$ складною, багатоаспектною сорерою суспільного буття, що пов'язана з економікою, культурою, політикою, рекреацією, освітою, спортом, духовним розвитком особистості [1, с. 34]. Слід зважати, що туризм суттєво впливає не тільки на життя окремої особистості, але й на розвиток людської цивілізації загалом [2, с. 109].

Туристично-рекреаційна ссрера характеризується специфічними рисами, які обумовлюють особливий підхід до їі регулювання, що передбачає вплив на економічні, політичні, соціальні, екологічні та інші процеси, що відбуваються в рамках керованого об'єкта та його взаємозв'язків [3, с. 152]. Втім, при проведенні аналізу туристично-рекреаційного потенціалу, як правило, враховуються далеко не всі важливі структурні складники й особливості їх прояву та відтворення, що не дає змоги виконати глибокий аналіз сутності й специфріки взаємозв'язків, які виникають між культурно-історичними, соціально-економічними, природничо-екологічними елементами системи [4, с. 11].

Аналіз останніх досліджень і публікацій. Проблеми розвитку туристично-рекреаційної сорери $€$ предметом дослідження багатьох науковців. Зокрема, Л.О. Мармуль [4] обґрунтовує доцільність застосування системно-структурного аналізу і синтезу для оцінювання ефективності рекреаційної діяльності. І.С. Благун та І.М. Гонак [5], О.В. Макара і Д.М. Гарасюк [6] дослідили концептуальні засади формування та фрункціонування туристично-рекреаційної системи. Ю.І. Гайда та В.І. Ілюк [7] запропонували авторський підхід до здійснення туристично-рекреаційного районування.

Окремо слід виділити наукову працю М.В. Шарко і П.В. Шмулевича [8], в якій досліджені синергетичні можливості бізнес-середовища, в якому формується новий туристичний продукт. Т.Є. Кунгурцева-Мащенко [9] присвятила своє дослідження проблемі застосування механізму генерації синергетичного ефректу в діяльності курортно-рекреаційного комплексу. Н.І. Моісєєва [10] обґрунтувала синергічну функцію туризму, яка реалізується через створення різнорівневого ринку туристичних послуг і підвищення рівня добробуту населення. Т. Скоробогатова [11] обґрунтувала виникнення ефекту синергізму як результат функціонування логістичних сервісних систем.

Як зазначає Л. Ткачук [2], дослідження туризму потребує інструментарію багатьох наук. Міждисциплінарний підхід дозволяє врахувати вплив численних чинників територіальної організації та розвитку туризму, відобразити його вплив на різні сфрери суспільства (економічну, політичну, соціальну, духовну).

Американські дослідники Ч. Голднер і Б. Рітчі [12] наполягають на тому, що дослідження феномену туризму має здійснюватися 3 урахуванням історичного, географрічного, інституційного, соціологічного, управлінського, економічного, системного підходів. 3 цим погоджується А.М. Гаврилюк [1], вказуючи на синергію означених підходів.

Виділення невирішених раніше частин загальної проблеми. Разом з тим, недостатньо дослідженими залишаються ознаки синергетичності туристично-рекреаційної системи, складність якої зростає високими темпами, а тому потребує принципово нових ідей для підвищення результативності фрункціонування у динамічному зовнішньому середовищі.

Формулювання цілей статті (постановка завдання). Метою дослідження $€$ обґрунтування ознак синергетичності туристичнорекреаційної соціо-еколого-економічної системи, що $€$ передумовою для підвищення есрективності управління ії розвитком на основі подолання небажаних фрлуктуацій та виходу на нові атрактори після проходження переломних точок біфуркації. 
Виклад основного матеріалу дослідження. Туристично-рекреаційну систему науковці трактують як сукупність взаємодіючих структур, елементів і явищ, які направлені на забезпечення туристських і рекреаційних потреб суспільства. Це сукупність мереж підприємств різних субгалузей туристичного господарства, що володіють як інтегральними, так і власними закономірностями розвитку 3 погляду територіальної диференціації економіки [6, с. 53-54].

Системність туризму пов'язують зі взаємодією різних суспільних інститутів, які розробляють та реалізують комплексні туристичні послуги. Водночас, суб'єктивно опосередкований характер туризму проявляється через його антропоцентричну складову, яка охоплює різні соціальні спільноти та індивідуально кожного туриста - суб'єкта туристичної сорери [1, с. 35].

Досліджувана система має певну ієрархію: на макрорівні йдеться про цілісність туристично-рекреаційної галузі в масштабах національної економіки, на мезорівні досліджуються самодостатність та унікальність туристично-рекреаційних районів, на мікрорівні спостерігається стратегічна організованість окремих підприємств і певна хаотичність поведінки окремих туристів. Відтак, можна стверджувати про залежність означеної системи, з одного боку, від мінливих потреб людини, а з іншого - від рівня науково-технічного прогресу, тенденцій розвитку світового ринку, державного регулювання тощо.

Елементи системи туризму можна класифрікувати за трьома групами: 1) господарство; 2) суспільство; 3) середовище. Серед складових системи найчастіше вказуються туристичні переваги, туристичні підприємства, людський капітал, управлінські інституції. Принциповим $є$ те, що дії кожного із суб'єктів впливають на поведінку інших суб'єктів, однак жоден з них не може контролювати фрункціонування цілісності системи [5, с. 90-91]. Відповідно, досліджуваній системі властива емерджентність, яка проявляється у виникненні нових структур, властивостей, моделей поведінки на макрорівні (туристично-рекреаційна галузь, туристичний ринок), що є результатом взаємодії елементів системи на мікрорівні (з одного боку, це рекреаційні потреби, туристські враження, мотивація щодо подорожей, вимоги до якості обслуговування, платоспроможність різних груп туристів, з іншого - стратегії поведінки суб'єктів, які співпрацюють/конкурують на туристичному ринку).
Компоненти туристично-рекреаційного потенціалу (природна, економічна, соціальна) $\epsilon$ відносно автономними, однак утворюють між собою стійкі взаємозв'язки і є взаємозалежними в межах туристично-рекреаційних систем і дестинацій [4, с. 14]. На нашу думку, це дає підстави стверджувати про наявність у туристично-рекреаційній системі синергетичного потенціалу, який може стати потужним імпульсом до розвитку в моменти кардинальної зміни кількісних і якісних характеристик туристично-рекреаційного споживання.

Синергетика досліджує сумісну дію багатьох підсистем, у результаті якої на макроскопічному рівні виникає нова структура, та іiі фрункціонування 3 результатом нової якості і рівня [13, с. 8]. Функціонування системи розглядається як безперервний процес виникнення та подолання суперечностей (конорліктів) між ії̈ елементами і довкіллям, a умовою існування й розвитку системи $€$ наявність механізмів усунення цих суперечностей $[13$, c. 15].

Перш за все, слід звернути увагу на складність туристично-рекреаційної системи. Складна система - це впорядкована множина структурно взаємопов'язаних взаємозалежних та фрункціонально взаємодіючих різнотипних елементів, які структурно об'єднані у цілісний об'єкт управління фрункціонально різнорідними взаємозв'язками для досягнення заданих цілей у певних умовах відсутності срормалізованої моделі [14, с. 15]. Гетерогенність і розмаїття такої системи породжують нові якості автокореляції, ампліфікації, мультиплікації.

Під соціо-еколого-економічною системою В.В. Якімцов розуміє "складну динамічну систему, що охоплює процеси виробництва, обміну, розподілу та споживання як матеріальних благ, так і соціально-екологічних ресурсів, потреб, можливостей на певний момент (термін, час, простір), так і у перспективі" [15, с. 21]. Вона складається з соціальної (суспільної), екологічної (довкілля), економічної (виробничої) ссрер. Ця система характеризується як складна, адже є: 1) емерджентною, тобто такою, в якій існують синергетичні зв'язки між елементами; 2) динамічною - яка враховує зміну параметрів у часі під впливом зовнішніх та внутрішніх чинників; 3) нелінійною, невизначеною щодо розвитку зовнішніх чинників, явищ, процесів [15, с. 21].

І.Б. Дегтярьова, О.І. Мельник, А.В. Бондар вважають, що еколого-економічні системи $\epsilon$ складними динамічними утвореннями, що 
перебувають у стані внутрішньої рівноваги тільки за умови балансу між асиміляційним потенціалом природного середовища та антропогенним навантаженням [16, с. 34].

В сучасних умовах усі природні та виробничо-соціально-економічні складові людської життєдіяльності виявились настільки взаємопов'язаними, що будь-який вплив на ту чи іншу природну компоненту призводить до непередбачуваних наслідків [17, с. 123]. В таких умовах синергетика надає науковий інструментарій для вивчення проблеми взаємодії економічної системи та довкілля, а також соціуму (соціального ефекту) [17, с. 125-126].

Основною ознакою соціо-еколого-економічної ефрективності (домінанта синергетичного ефректу) $€$ виробництво споживчих вартостей 3 метою задоволення суспільних потреб, з одного боку, та спрямованість на задоволення специорічних потреб у належних соціальних та екологічних умовах - 3 іншого $[13$, с. 16]. Прояв позитивного еколого-економічного синергізму у різних секторах національної економіки обумовлюється посиленням екологічних фрункцій [16, с. 35]. Тому при розробці стратегії розвитку соціально-економічних систем доцільно враховувати синергетизм взаємодії природного середовища і антропогенних систем, вплив стану середовища на результати виробничої діяльності підприємств [18, с. 102-103]. Відповідно, синергетичний тип сталого розвитку проявляється насамперед у тому, що він об'єднує у цілісну систему як мінімум три сфери людської діяльності - економічну, соціальну і екологічну, створюючи системний ефект сталого розвитку [18, с. 117].

Таким чином, туристично-рекреаційна галузь пов'язана з суміжними галузями економіки та елементами суспільного життя когерентними зв'язками, які передбачають синхронізацію, узгодження їх життєвих циклів. 3 іншого боку, розвиток цієї галузі співвідноситься з еволюцією природних систем, що потребує їх взаємопристосування за допомогою коеволюційних механізмів.

Сутність синергетичного підходу до управління полягає в тому, що він орієнтований на власні закони еволюції та самоорганізації систем [13, с. 15]. Це дає змогу перейти від системи управління, заснованої на зовнішньому впливі, до гармонічного поєднання впливу та самоорганізації $[19$, с. 219].

Самоорганізація описується як процес виникнення впорядкованих просторово-часових структур в далеких від рівноваги станах поблизу точок біфруркації, де поведінка системи стає нестійкою і під впливом незначних відхилень може різко змінити свій стан. Стан системи після проходження точок біфруркації може оцінюватися як анергічний (довготривалий стійкий стан) і реотропічний (недостатньо стійкий) [13, с. 18]. Урахування синергетичних ефректів дає змогу розробити механізми управління розвитком складних систем у точках біфруркації за допомогою інструментів правового, адміністративного, соціальнопсихологічного, інфрормаційно-інноваційного характеру [16, с. 32-33].

У результаті прояву самоорганізаційних властивостей система генерує синергетичний потенціал, здатний через пошук множини чинників впливу та нестабільних станів вивести ії на траєкторію сталого розвитку [20, с. 51]. У процесі управління потенціалом системи доцільно проаналізувати кожен ії елемент та фрактори, які на нього впливають. Позитивний результат об'єднання елементів можливий лише тоді, коли кожна зі складових потенціалу (економічна, соціальна, екологічна) буде підсилювати іншу.

Отже, туристично-рекреаційна сорера може розглядатися як складна соціо-еколого-економічна система з ознаками синергетичності, що означає здатність за рахунок взаємодії внутрішніх структурних якостей 3 потоками, що надходять ззовні, до створення структурно та інфрормаційно матеріалізованої нової якості. Своєрідними "новими продуцентами" можуть вважатися враження туристів та рекреантів від подорожі, які надихатимуть їх на різноманітні вчинки, як-то пожертвування на реставрацію історико-культурних пам'яток, придбання житла у певній місцевості, написання віршів (музики, картин тощо) або просто підвищення продуктивності праці після відпочинку.

Туристично-рекреаційна система розвивається за законами синергетичної циклічності з поєднанням процесів організації та самоорганізації (рис. 1).

На розвиток туристично-рекреаційної системи впливає велика кількість фрлуктуацій у вигляді соціально-економічних, особистісноповедінкових, ресурсно-екологічних, політичних та інших чинників. Переплітаючись, вони формують фрлуктуаційний фон, у контексті якого в різних груп людей у певний момент часу виникає інтерес до природних та культурних пам'яток тієї чи іншої території (своєрідний запуск механізму просторово-часової самоорганізації). 
По мірі самовільного поширення інформації (прояв самоорганізації), а також у результаті креативної реклами туристичних підприємств і виваженої державної (регіональної) політики (зовнішній вплив) збільшується потік туристів, з'являються нові інсрраструктурні об'єкти. У масовій свідомості формується установка, що ресурси району є унікальними. На нашу думку, цей момент асоціюється 3 точкою бісруркації, проходження якої означає незворотну трансорормацію території у туристично-рекреаційний район - складний адміністративно-господарський організм, в якому сорера туризму і рекреації виступає системоформуючою компонентою для розвитку промислових, торговельних, транспортних, будівельних, культурно-побутових та інших організацій, сумісна діяльність яких генерує ефрект мультиплікативності.

Проходження системою через точки бісруркації супроводжується якісними перетвореннями, які змінюють цикли рекреаційної діяльності, рекреаційну місткість та освоєність різних територій. Такі зміни, зокрема, відбуваються в сучасних умовах пандемії: у геограсрічному контексті атрактивними стають території, безпечні для відвідування з точки зору можливості дотримання соціальної дистанції, у фрінансовому - прагнення отримати максимум вражень від відпочинку з мінімальними витратами, у технологічному - поширення "віртуальних подорожей".

Отже, у точці біфуркації перед системою відкривається безліч шляхів еволюції і здійснюється вибір атрактора. Атрактор можна розглядати як бажану ціль системи, до якої остання прагне, але яка може бути не досягнута через відсутність необхідних і достатніх умов. За нашим переконанням, атракторами досліджуваної системи є природні, історикокультурні і соціально-економічні ресурси, що характеризуються унікальністю, оригінальністю, естетичною привабливістю, цілющооздоровчою значимістю, мають сприятливі для туристично-рекреаційної діяльності якісні і кількісні параметри та виступають матеріальною основою для фрормування і спеціалізації туристично-рекреаційних районів. Відповідно, атрибутивні характеристики місць, які $\epsilon$ кінцевими або проміжними точками туристичного маршруту, впливають на функціонування кожного компонента туристичної системи [2, c. 109].

Конкуренція атракторів можлива за такими критеріями, як: обсяг запасів, площа поширення, період можливої експлуатації, вар- тість експлуатаційних затрат, універсальність, соціальність, масовість, унікальність, доступність тощо. Вважаємо, що один з глобальних атракторів еволюції туристично-рекреаційної системи асоціюється з унісрікацією туристичних та рекреаційних продуктів під впливом вирівнювання показників рекреаційного споживання і туристських запитів в умовах глобалізації туристичного ринку, тоді як інший (протилежний) тяжіє до подальшої диференціації потреб, інтересів, цінностей і мотивів людей у сфрері відпочинку, дозвілля, подорожей, а також диверсисрікованості підходів до туристично-рекреаційного районування територій, класифрікації туристично-рекреаційних ресурсів і формування стратегій розвитку сорери туризму.

Після проходження точки біфруркації стрімко збільшуються інвестиції у розвиток туристично-рекреаційного району, має місце приплив робочої сили, в результаті чого відбувається поступова асиміляція місцевих мешканців в їх середовищі, що нерідко призводить до втрати місцевої культури та фрормування нової. Згідно з концепцією "демонстраційного есректу”, експансія великої кількості подорожуючих підсилює роль туризму як чинника дифузії культурних зразків, що найактивніше відбувається у несуттєво змінених сучасною культурно-уніфрікованою цивілізацією перифрерійних регіонах світу. Поведінкові моделі, які демонструють туристи при контакті з місцевою культурою, можуть варіюватися від культурного шоку (стану спантеличення, емоційного збурення), до культурної зверхності та зневаги (ігнорування традицій, устоїв та етичних норм приймаючої спільноти) [2, с. 110].

На цьому етапі, вочевидь, у системі наростає ентропія, під якою розуміють втрати руху матерії і людської діяльності, що мають симбіотичний характер. Часто спостерігаються незворотні екологічні зміни, через що регіон втрачає свою атрактивність. Зокрема, стихійне рекреаційне освоєння може призводити до втрати природними комплексами їх лікувальних, оздоровчих, пізнавальних, естетичних чи інших властивостей (так звана рекреаційна дигресія) [21, с. 24]. Вважаємо, що перевищення критично допустимого рекреаційного навантаження території може призвести до негативної синергії, що означає не лише відсутність ефекту відновлення сил, але й накопичення негативних емоцій, переживання стресових ситуацій (потенційну шкоду для здоров'я людей), а також збитки для суб'єктів господарської діяльності. Це вима- 


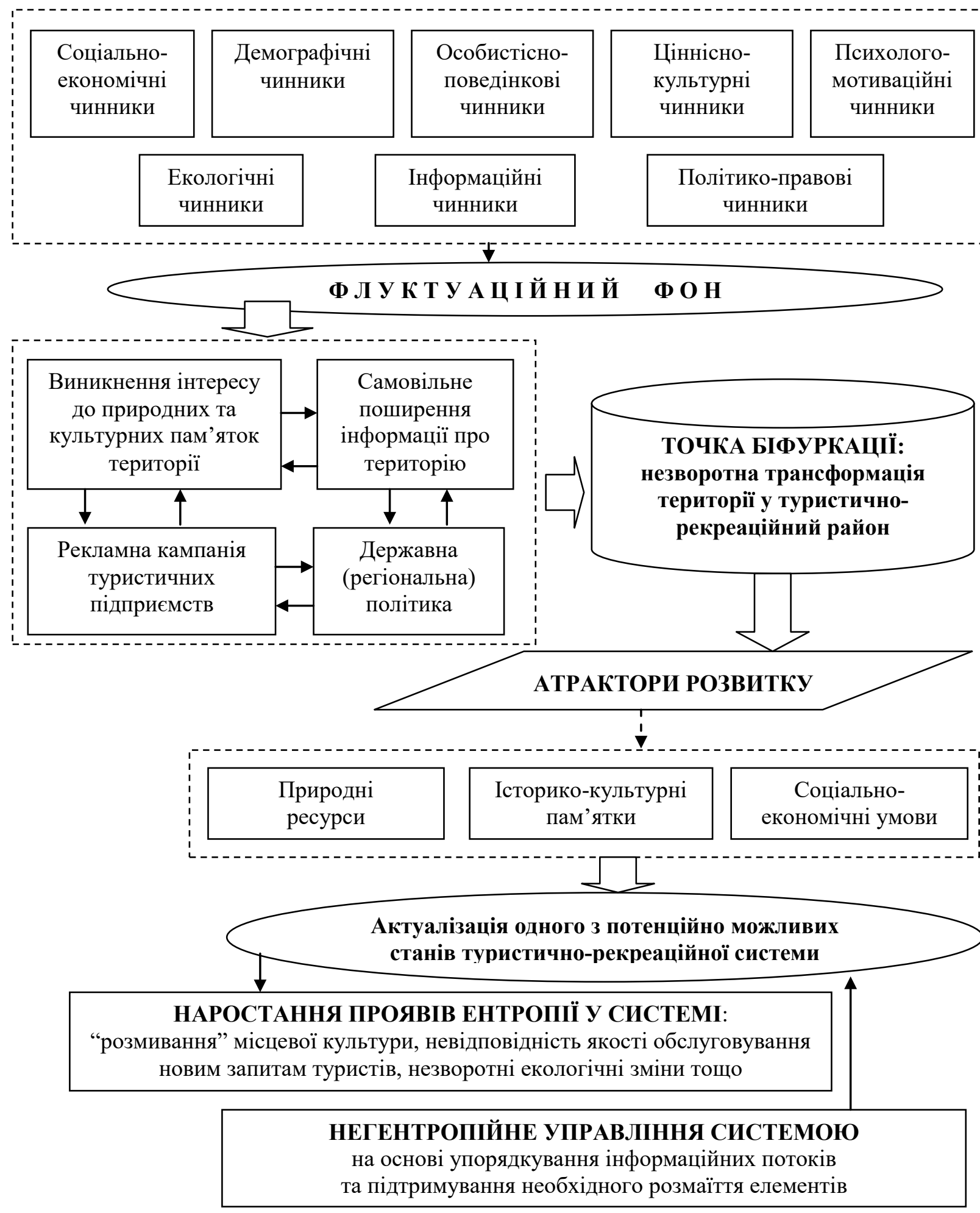

Рис. 1. Синергетична інтерпретація життєвого циклу туристично-рекреаційної системи Джерело: авторська розробка

гає створення стратегічних і поточних планів, які коригують людську діяльність залежно від змін ентропії природи [22, с. 23].

Кожна система, намагаючись зберегти стійкість, протидіє ентропії через інсрормаційну активність. Так, інструментами подо- лання наростаючої ентропії природних процесів можуть виступати заходи з рекреаційного природокористування, фрункціональне зонування рекреаційних територій, визначення допустимого рекреаційного навантаження, раціональна просторово-територіальна орга- 
нізація рекреаційних закладів тощо. Для протидії "ентропії соціально-культурного життя" доцільно дбати про збереження культурної самобутності народів і підвищення якості туристичного продукту. 3 негентропійним упорядкуванням системи також пов'язане туристично-рекреаційне районування - "послідовний процес просторового впорядкування інформації, що дозволяє комплексно оцінити особливості розміщення досліджуваних явищ і об'єктів та їх територіальної організації" [7]. Просторово-інооомаційне впорядкування території дозволяє досягати таких синергетичних ефектів: 3 найбільшою ефективністю визначити можливості використання тих або інших територій для цілей рекреації і туризму; виділяти нові рекреаційно-туристичні райони; виявляти нові рекреаційні ресурси й інші передумови для розвитку рекреації в ще не освоєних місцевостях; переносити досвід розвитку рекреації з одних районів до інших [23, с. 168].

Втім, завдання максимізації стійкості полягає не у повному усуненні ентропії, а в забезпеченні оптимального рівня співвідношення між порядком і хаосом. Іншими словами, у процесі формування і розвитку туристичнорекреаційних комплексів не варто прагнути максимальної стійкості, оскільки досягнута сталість, гомогенність і цілісність 3 часом почне знижувати їх атрактивність і можливість адаптуватися до нових запитів туристів і рекреантів.

Управління соціо-еколого-економічними системами пов'язане 3 проблемою вибору траєкторії еволюції систем: соціальна підсистема має особливості, пов'язані як зі специфрікою людського особистісного фрактора, так і соціально-системними властивостями інфрормаційної системи, яка їм відповідає; екологічна підсистема розвивається на основі закономірностей еволюції природного середовища; економічна підсистема "притягується" атрактором у вигляді точки оптимуму "витрати - прибуток". Синергетичний підхід до забезпечення сталого розвитку передбачає, що: забезпечується оптимальне співвідношення процесів організації, самоорганізації і управління; основу розвитку становить економічна, екологічна і соціальна рівновага, а управління розвитком галузі орієнтоване в першу чергу на самоорганізацію, пошук інновацій, на дотримання і впровадження нових технологій [20, с. 49].

На нашу думку, для управління туристично-рекреаційною системою доцільно застосовувати синергетичну модель, провід- ним елементом якої $\epsilon$ інфрормаційна структура, що охоплює сукупність каналів масової комунікації, інфрормаційних технологій, взаємопов'язаних організаційних правил збирання і використання інфрормації. Застосування синергетичної методології управління націлюватиме на пошук інноваційних методів задоволення туристських і рекреаційних потреб, підвищення адаптивності туристичного продукту до змін ринкової кон'юнктури, а також збільшення соціо-еколого-економічної ефрективності туризму і рекреації. Методичною основою синергетичного управління виступають моніторингова діагностика формування в області біфуркації нових параметрів порядку, визначення можливих атрактивних станів, вибір з них бажаного і розробка засобів для "підштовхування" системи до цього стану (рис. 2).

Висновки 3 проведеного дослідження. Таким чином, синергетичність туристичнорекреаційної системи обумовлюється її нелінійністю, відкритістю, емерджентністю властивостей, когерентною та коеволюційною взаємодією 3 іншими елементами суспільного життя, галузями економіки, природними системами. Самоорганізація означеної системи пояснюється передусім визначальною роллю людського чинника: неповною детермінованістю мотивів туристської поведінки, мінливістю рекреаційних потреб і запитів щодо рівня обслуговування. Сфера рекреації і туризму також постійно відчуває потужні фрлуктуаційні впливи економічного характеру, що пов'язано з коливаннями у кон'юнктурі туристичного ринку, високим рівнем конкуренції, змінами у платоспроможному попиті і рівнях цін на туристичний продукт.

Еволюція туристично-рекреаційної системи має ознаки синергетичної циклічності і супроводжується наростанням ентропії у вигляді невпорядкованості у культурному (зміна стилю життя місцевого населення), природному (прояви рекреаційної дигресії) та економічному (зниження рентабельності надання туристичних послуг) середовищі. Аналогом негентропії $€$ досягнення інфрормаційної упорядкованості системи завдяки управлінському впливові.

Особливо затребуваною синергетична методологія управління стає у точках біфуркації, що означають якісну трансформацію системи (зокрема, в умовах пандемії). В сучасних умовах необхідно здійснювати моніторинг рівня ентропії у туристично-рекреаційних структурах, нейтралізувати небажані фрлукту- 


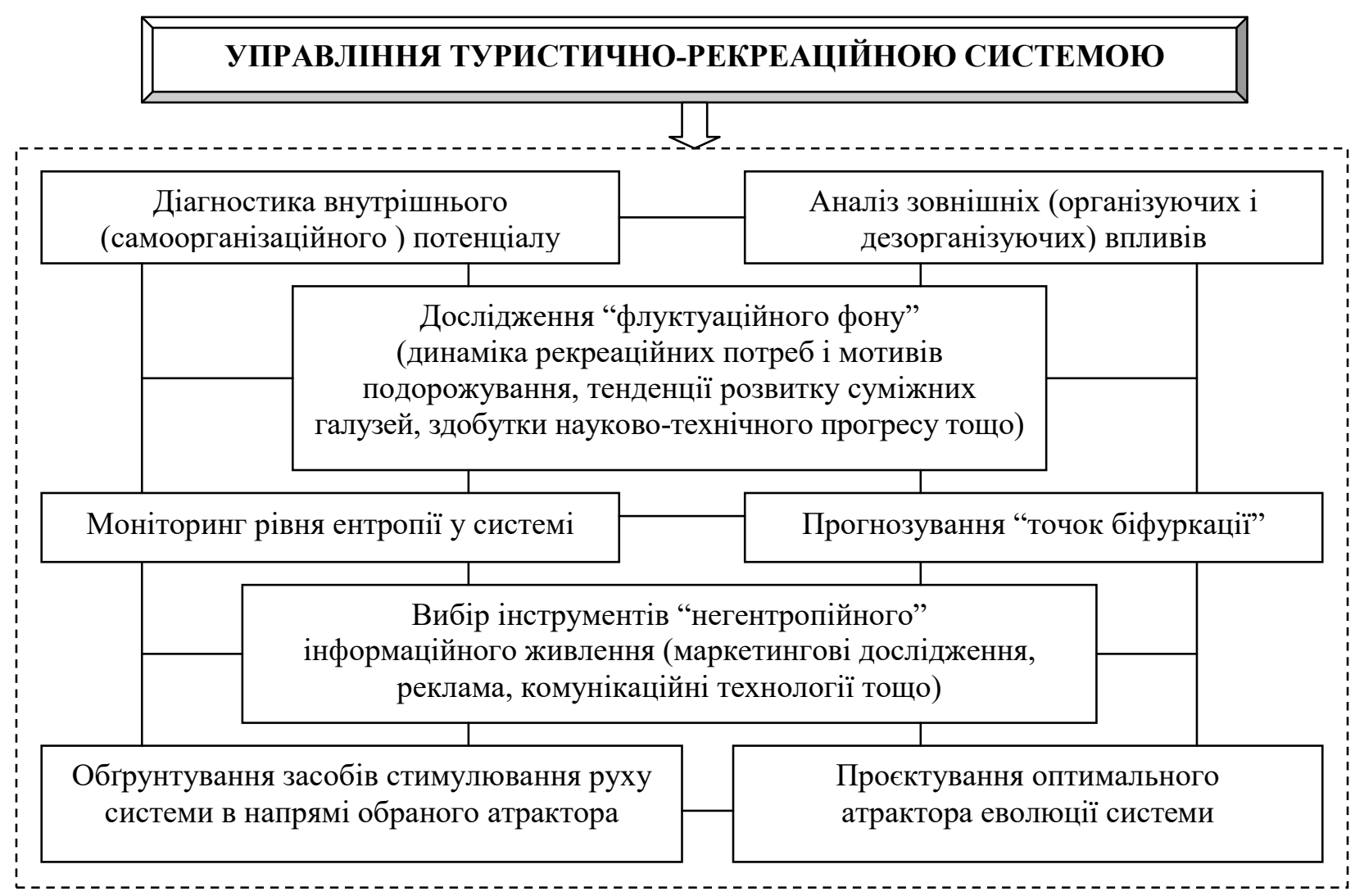

Рис. 2. Базові положення синергетичної моделі управління розвитком туристично-рекреаційної системи

Джерело: авторська розробка

ації і прогнозувати точки бісруркації з метою своєчасного впровадження інновацій та виведення системи на бажаний атрактор еволюції.

Перспективи подальших досліджень полягають у необхідності удосконалення методики туристично-рекреаційного районування як дієвого методу підвищення інформаційної та просторово-часової упорядкованості сфрери туризму та рекреації після проходження точок біфруркації.

\section{СПИСОК ВИКОРИСТАНИХ ДЖЕРЕЛ:}

1. Гаврилюк А.М. Теоретико-методологічні аспекти обґрунтування френомену туризму як соціального інституту держави. Вчені записки Таврійського національного університету імені В.І. Вернадського. Серія “Державне управління”. 2018. Т. 29 (68). № 3. С. 34-39.

2. Ткачук Л. Сутність туризму як багатоаспектного суспільного явища. Вісник Київського національного університету імені Тараса Шевченка. Серія “Географія”. 2017. Вип. 1-2 (66-67). С. 109-113.

3. Родіонова І.В. Фінансове забезпечення розвитку туристично-рекреаційної ссеери в Україні. Вісник Хмельницького національного університету. Серія “Економічні науки”. 2017. № 1. С. 152-155.

4. Мармуль Л.О. Визначення ефективності функціонування рекреаційних підприємств та відтворення їх ресурсів на засадах системно-структурного аналізу і синтезу. Агросвіт. 2019. № 11. С. 10-15.

5. Благун І.С., Гонак І.М. Концептуальні основи фрормування територіальної рекреаційної системи. Вісник Чернівецького торговельно-економічного інституту. Серія “Економічні науки”. 2014. Вип. 4. С. 86-96.

6. Макара О.В., Гарасюк Д.М. Теоретичні основи фрормування територіальних туристично-рекреаційних систем. Науковий вісник Полтавського університету економіки і торгівлі. Серія "Економічні науки". 2014. № 2. С. 53-58.

7. Гайда Ю.І., Ілюк В.І. Туристично-рекреаційне районування України: емпірично-статистичний підхід. Ефективна економіка. 2020. № 2. URL: http://www.economy.nayka.com.ua/?op=1\&z=7645 (дата звернення: 09.04.2021). 
8. Шарко М.В., Шмулевич П.В. Использование синергии в сфрере туризма. Інфрраструктура ринку. 2017. Вип. 11. C. 87-92.URL: http://www.market-infr.od.ua/journals/2017/11_2017_ukr/17.pdf(дата звернення: 21.01.2021).

9. Кунгурцева-Мащенко Т.Є. Синергетичний ефект у діяльності курортно-рекреаційних систем в умовах інтеграційного розвитку. Глобальні та національні проблеми економіки. 2018. Вип. 23. С. $706-709$. URL: http://global-national.in.ua/archive/23-2018/136.pdf (дата звернення: 21.01.2021).

10. Моісєєва Н.І. Інноваційність туристичної сорери регіону в умовах сталого розвитку: стратегічний вимір : автореф. дис. ... докт. екон. наук : 08.00.05; Одеська національна академія харчових технологій. Одеса, 2019. 43 с.

11. Скоробогатова Т. Образование синергетического эфрфекта в туризме как результат фрункционирования логистических сервисных систем. Вісник економічної науки України. 2012. № 2(22). С. 147-151.

12. Goeldner C.R., Ritchie J.R.B. Tourism: principles, practices, philosophies. N.Y. : John Wiley \& Sons, 2009.657 p.

13. Якімцов В.В. Теоретико-методологічні засади синергетичної ефективності фрункціонування складних соціо-еколого-економічних систем : автореф. дис. ... докт. екон. наук : 08.00.06; Львівський національний аграрний університет. Львів, 2019. 42 с.

14. Фадєєва І.Г. Обґрунтування доцільності застосування системно-синергетичного підходу до управління розвитком нафтогазовидобувних корпоративних систем. Інвестиції: практика та досвід. 2014. № 17. С. $13-19$.

15. Якімцов В.В. Теоретико-методологічні засади синергетичної ефективності функціонування соціо-еколого-економічних систем. Збалансоване природокористування. 2018. № 4. С. 20-26.

16. Дегтярьова І.Б., Мельник О.І., Бондар А.В. Синергетичні ефекти еколого-економічних систем в умовах інформаційної економіки. Механізм регулювання економіки. 2013. № 3. С. 30-37.

17.Якімцов В. Методологічні аспекти синергетичного дослідження соціо-еколого-економічних систем. Економічний дискурс. 2018. Вип. 3. С. 123-134.

18. Загорський В.С. Концептуальні основи фрормування системи управління сталим розвитком екологоекономічних систем : монографрія. Львів : ЛРІДУ НАДУ, 2018. 336 с.

19. Коломієць С.В. Управління соціально-економічними системами: синергетичний підхід. Причорноморські економічні студії. 2020. Вип. 51. С. 215-220.

20. Лисенко Ю.В. Синергетика сталого розвитку галузей промисловості України. Причорноморські економічні студії. 2017. Вип. 13-1. С. 48-52.

21. Чир Н.В. Рекреаційна географрія : навчально-методичний посібник. Мукачево : вид-во Дишкант С.Я., 2019. 156 c.

22. Чаленко О.Ю. Самоорганізація, ентропія в природі та економіці. Наука та інновації. 2013. Т. 9. № 4. С. 13-24.

23. Поколодна М.М. Рекреаційна географрія : навчальний посібник. Харків : ХНАМГ, 2012. 275 с.

\section{REFERENCES:}

1. Ghavryljuk A.M. (2018) Teoretyko-metodologhichni aspekty obgruntuvannja fenomenu turyzmu jak socialjnogho instytutu derzhavy [Theoretical and methodological aspects of the foundation of tourism phenomen as a social institution of the state]. Vcheni zapysky Tavrijsjkogho nacionaljnogho universytetu imeni V.I. Vernadsjkogho. Serija "Derzhavne upravlinnja" [Scientific Notes of V.I Vernadsky Taurida National University. Public Administration], vol. 29(68), no. 3, pp. 34-39.

2. Tkachuk L. (2017) Sutnistj turyzmu jak baghatoaspektnogho suspiljnogho javyshha [Tourism as a multidimensional phenomenon]. Visnyk Kyivskogo natsionalnogo universytetu. Serija "Geografiya" [Bulletin of Taras Shevchenko National University of Kyiv. Geography], vol. 1-2 (66-67), pp. 109-113.

3. Rodionova I.V. (2017) Finansove zabezpechennja rozvytku turystychno-rekreacijnoji sfery v Ukrajini [Financial support of tourist and recreational areas in Ukraine]. Visnyk Khmeljnycjkogho nacionaljnogho universytetu. Serija "Ekonomichni nauky" [Herald of Khmelnytskyi National University. Economic Sciences], no. 1, pp. 152-155.

4. Marmul L.O. (2019) Vyznachennja efektyvnosti funkcionuvannja rekreacijnykh pidpryjemstv ta vidtvorennja jikh resursiv na zasadakh systemno-strukturnogho analizu i syntezu [Determination of the efficiency of the functioning of recreational enterprises and the reproduction of their resources on the basis of system structural analysis and synthesis]. Aghrosvit [Agrosvit], no. 11, pp. 10-15.

5. Blahun I.S., Honak I.M. (2014) Konceptualjni osnovy formuvannja terytorialjnoji rekreacijnoji systemy [Conceptual foundations of territorial recreation system formation]. Visnyk Chernivecjkogho torghoveljno-ekonomichnogho instytutu. Serija "Ekonomichni nauky" [Herald of the Chernivtsi Trade and Economic Institute. Economic Sciences], vol. 4, pp. 86-96.

6. Makara O.V., Harasyuk D.M. (2014) Teoretychni osnovy formuvannja terytorialjnykh turystychno-rekreacijnykh system [Theoretical fundamentals of forming territorial tourist and recreational systems]. Naukovyj visnyk Pol- 
tavsjkogho universytetu ekonomiky i torghivli. Serija "Ekonomichni nauky" [Scientific Bulletin of Poltava University of Economics and Trade. Economic Sciences], no. 2, pp. 53-58.

7. Hayda Ju.I., Iliuk V.I. (2020) Turystychno-rekreacijne rajonuvannja Ukrajiny: empirychno-statystychnyj pidkhid [Tourist and recreation zoning of Ukraine: empirical-statistical approach]. Efektyvna ekonomika [Efficient Economy] (electronic journal), no. 2. Available at: http://www.economy.nayka.com.ua/?op=1\&z=7645 (accessed 9 April 2021).

8. Sharko M.V., Shmulevich P.V. (2017) Ispol'zovanie sinergii v sfere turizma [Use of synergy in the field of tourism]. Infrastruktura rynku [Market Infrastructure] (electronic journal), vol. 11, pp. 87-92. Available at: http://www.market-infr.od.ua/journals/2017/11_2017_ukr/17.pdf (accessed 21 January 2021).

9. Kunghurceva-Mashhenko T.Je. (2018) Synerghetychnyj efekt u dijaljnosti kurortno-rekreacijnykh system $v$ umovakh integhracijnogho rozvytku [Synergetic effect in activity of resort-recreation systems in the conditions of integration development]. Ghlobaljni ta nacionaljni problemy ekonomiky [Global and National Problems of the Economy] (electronic journal), vol. 23, pp. 706-709. Available at: http://global-national.in.ua/archive/23-2018/136.pdf (accessed 21 January 2021).

10. Moisjejeva N.I. (2019) Innovacijnistj turystychnoji sfery reghionu v umovakh stalogho rozvytku: strateghichnyj vymir [Innovation of the tourist sphere of the region in the conditions of sustainable development: strategic dimension] (PhD Thesis), Odessa: Odessa National Academy of Food Technologies.

11. Skorobogatova T. (2012) Obrazovanie sinergeticheskogo effekta v turizme kak rezul'tat funktsionirovaniya logisticheskikh servisnykh sistem [Formation of synergetic effect in tourism as result of functioning of logistic service systems]. Visnyk ekonomichnoji nauky Ukrajiny [Herald of Economic Science of Ukraine], no. 2(22), pp. 147-151.

12. Goeldner C.R., Ritchie J.R.B. (2009) Tourism: principles, practices, philosophies. N.Y.: John Wiley \& Sons, 657 p.

13. Yakimtsov V.V. (2019) Teoretyko-metodologhichni zasady synerghetychnoji efektyvnosti funkcionuvannja skladnykh socio-ekologho-ekonomichnykh system [Theoretical and methodological principles of synergetic efficiency of complex socio-ecological and economic systems functioning] (PhD Thesis), Lviv: Lviv National Agrarian University of the Ministry of Education and Science of Ukraine.

14. Fadeeva I.Gh. (2014) Obgruntuvannja dociljnosti zastosuvannja systemno-synerghetychnogho pidkhodu do upravlinnja rozvytkom naftoghazovydobuvnykh korporatyvnykh system [The substantiation of the appropriatness of application of the system-synergetic approach to management of the development of oil and gas production corporate systems]. Investyciji: praktyka ta dosvid [Investment: Practice and Experience], no. 17, pp. 13-19.

15. Yakimtsov V.V. (2018) Teoretyko-metodologhichni zasady synerghetychnoji efektyvnosti funkcionuvannja socio-ekologho-ekonomichnykh system [Theoretical and methodological principles of synergetic efficiency of socio-ecological-economic systems functioning]. Zbalansovane pryrodokorystuvannja [Balanced Nature Using], no. 4, pp. 20-26.

16. Dehtyarova I.B., Melnyk O.I., Bondar A.V. (2013) Synerghetychni efekty ekologho-ekonomichnykh system $v$ umovakh informacijnoji ekonomiky [Synergetic Effects of Ecological and Economic Systems in Information Economy]. Mekhanizm reghuljuvannja ekonomiky [Mechanism of Economic Regulation], no. 3, pp. 30-37.

17. Yakimtsov V. (2018) Metodologhichni aspekty synerghetychnogho doslidzhennja socio-ekologho-ekonomichnykh system [Methodological aspects of synergetic research about socio-ecological and economic systems]. Ekonomichnyj dyskurs [The Economic Discourse], vol. 3, pp. 123-134.

18. Zaghorsjkyj V.S. (2018) Konceptualjni osnovy formuvannja systemy upravlinnja stalym rozvytkom ekologho-ekonomichnykh system [Conceptual foundations of sustainable developments management system of ecological and economic systems formation]. Lviv: LRIDU NADU. (in Ukrainian)

19. Kolomiiets S.V. (2020) Upravlinnja socialjno-ekonomichnymy systemamy: synerghetychnyj pidkhid [Management of socio-economic systems: synergistic approach]. Prychornomorsjki ekonomichni studiji [Black Sea Economic Studies], vol. 51, pp. 215-220.

20. Lysenko Ju.V. (2017) Synerghetyka stalogho rozvytku ghaluzej promyslovosti Ukrajiny [Synergetic of sustainable development of Ukrainian industries]. Prychornomorsjki ekonomichni studiji [Black Sea Economic Studies], vol. 13-1, pp. 48-52.

21. Chyr N.V. (2019) Rekreacijna gheoghrafija [Recreational Geography]. Mukachevo: Dyshkant S.Ja. (in Ukrainian)

22. Chalenko O.Y. (2013) Samoorghanizacija, entropija v pryrodi ta ekonomici [Self-Organization, Entropy in Nature and Economics]. Nauka ta innovaciji [Science and Innovation], vol. 9, no. 4, pp. 13-24.

23. Pokolodna M.M. (2012) Rekreacijna gheoghrafija [Recreational Geography]. Kharkiv: Kharkiv National Academy of Municipal Economy. (in Ukrainian) 